Article

\title{
From Collaborative to Hegemonic Water Resource Governance through Dualism and Jeong: Lessons Learned from the Daegu-Gumi Water Intake Source Conflict in Korea
}

\author{
Ki Woong Cho ${ }^{1}$ and Kyujin Jung ${ }^{2, *}$ (i) \\ 1 Department of Public Administration and New Publicness Education and Research in the New Normal Era, \\ Brain Korea 21 Plus, Korea University, Seoul 02841, Korea; kc2632@caa.columbia.edu \\ 2 Department of Public Administration and the Graduate School of Governance, Sungkyunkwan University, \\ Seoul 03063, Korea \\ * Correspondence: kjung1@skku.edu; Tel.: +82-2-760-0253
}

Received: 24 October 2018; Accepted: 20 November 2018; Published: 25 November 2018

check for updates

\begin{abstract}
Recently, water supplies have been insufficient in some areas. In South Korea, using dualism and Jeongish citizenship, we will demonstrate why collaborative governance of the Daegu-Gumi Water Commission has not worked and how it has been mismanaged by its stakeholders. We discuss the conflict between the Daegu Metropolitan City (hereafter referred to as City of Daegu) and the City of Gumi regarding the relocation of the water intake source. In response to many water pollution accidents, the City of Daegu decided to move the water intake source to near the City of Gumi. Due to a conflict between the cities on this issue, the city established a collaborative governance entity, the Daegu-Gumi Water Commission. However, this form of governance was not successful, and eventually, the Daegu-Gumi Water Commission moved from collaborative governance to hegemonic governance. This was due to dualism and Jeongish citizenship with weak membership, participation, experience, and social capital on the local level as South Korean civil societies tend to have insufficient power and experience to fulfill their intentions or negotiate successfully. The Daegu-Gumi Water Commission failed to reach a consensus and to realize a truly collaborative governance process.
\end{abstract}

Keywords: collaborative governance; hegemonic governance; water resource governance; South Korea

\section{Introduction}

In South Korea, the expression "spending money like water" means that one uses money as if the amount is infinite. The statement likely became popular because of the seemingly endless supply of water. Currently, South Korea's water stress level (40-80\%) is high [1]. The average annual precipitation per person in South Korea is $2673 \mathrm{~m}^{3}$, which is one-sixth of the world average [2]. One of the main causes of the persistent water supply shortages in South Korea is the heavy focus on the available water quantity from short-duration rainfall via floods or heavy rains, which prevents stakeholders from managing water efficiently [2]. In recent years, the above expression could not have been used very much in South Korea. To manage water efficiently and effectively, many organizations need to collaborate, which can be called water resource governance. As an infrastructure that requires a large amount of time and money, water resource management needs government support alongside private collaboration [3].

In South Korea, this complex water management system involving various government branches also causes problems relating to inefficiency. For instance, depending on the area of water management, 
the supervising government such as the Ministry of Environment for hydro-Meteorological events and the Ministry of Land, Infrastructure and Transport for managing streams is different [4]. Particularly, South Korea has struggled to solve the water resource problems of water distribution and usage because of the unbalanced water supply and demand, dispersed water management departments, and a lack of water management principles and systematic data [5].

However, there are positive and negative aspects regarding governance [6,7]. Some argue that governance can be considered a third political project for reform in order to overcome the problems caused by both the Keynesian welfare state and market-oriented neo-liberalism [8]. However, Swyngedouw [9] argues that governance is rooted in neo-liberal ideology, which then promotes neo-liberal globalization.

Furthermore, the Confucian philosophy in Korea makes governance stakeholders different from those in other countries, such as the United States. Jeong is usually mentioned as a positive aspect of Korean culture that has maintained Korean civil society even before the country was democratized in 1987. In South Korea, an interesting example of a water governance issue is the conflict of the location of the water intake plant in Gyeongsang Province. This conflict between the City of Daegu and the City of Gumi is important in explaining the conflicts among governance stakeholders (local governments, civil societies, and citizens, and so on).

Thus, in this study, we explore how governance works and whether, after agenda setting, it works well in South Korea. Facing the water shortage era, we would like to examine water shortage solutions that use governance approaches and how these approaches vary depending on the culture and situation from which they arise. By examining dualism and the Jeongish culture of Confucianism in South Korea, we demonstrate how and why collaborative governance has not worked well and why it has transformed into hegemonic governance.

\section{Theoretical Considerations}

\subsection{Water Resource Governance}

To deal with a large amount of water resources, rather than using a command-and-control paradigm, it is common for the private sector and nonprofit groups to become involved in water resources governance alongside different government departments [10]. From this, there has been a recent transition toward integrated water resource governance [10]. Governments are collaborating more with other organizations and governance systems. Additionally, more than 300 rivers run across two or more countries [2] and subsequently, sometimes those shared rivers cause conflict (e.g., the Rhine River runs through Germany, France, Austria, and the Netherlands; the Jordan River runs through Israel, Jordan, Lebanon, and Syria; and the Nile River runs through nine countries [2]. To resolve these conflicts, these countries must collaborate. For example, the Netherlands Water Partnership, established in 1999 to boost the water industry and support its foreign advance, has registered more than 200 organizations, including government departments, public agencies, firms, non-governmental organizations (NGOs), and research institutions [3]. Several meetings and collaborations-The World Water Conferences at Mar del Plata in 1977 [11], The Dublin Conference on Water and the Environment in 1992, and the Water Cooperation Facility in 2004, for example-have been held to resolve water conflicts [2]. For successful water resource governance to occur, scholars have argued that various components from different areas must be applied. These include cooperation and inclusiveness in South Africa [12], and participation has boosted the success of water governance in South Africa [13,14], Kenya [15], India [16], and New Zealand [17].

While Lennox et al. (2011) maintains the necessity of collaborative governance, these studies and examples insufficiently describe how water governance has modified or transformed in accordance with environmental changes. Furthermore, they do not sufficiently review water conflict where collaborative governance was attempted but was not successful. The unsuccessful cases also provide lessons for future governance and policy implementation. 
Collaboration among governments, NGOs, and the private sector has a long history. Governments have already begun to cooperate with other actors for more successful implementation because governments alone cannot address all parts of their complex policies. There are various definitions of governance, some of which are ambiguous [8]. Rhodes [18,19] defines governance in the present-day use as "a new process of governing; or a changed condition of ordered rule; or the new method by which society is governed." Governance in an open and democratic society refers to the many sources of rules that individuals use [20].

Governance can be categorized into three types: market, hierarchy, and network governance $[8,21]$. This explanation is associated with government, market, and civil society governance [8] but, depending on the country, the key players are different. Considering the culture of each country, we can think about the three types of governance: government-centered governance, market-centered governance, and civil society-centered governance. If the government's role is mainly about control, then this is called government-centered governance; this is common in Asian countries such as South Korea, China, and Japan. In contrast, in the United States and the United Kingdom, for example, if the market takes a central role, this is called market-centered governance. Finally, if civil society, including NGOs, play a central role then this is civil society-centered governance; this is the case in France and Germany. The role of governance can be applied in local, international, and national areas [8]. In governance, the central government also cooperates with local governments by empowering local governments with central government power through decentralization [22,23].

In governance, to implement better policies and save costs, social actors, including the government, civil society, and the market, along with interest groups and experts, should cooperate. Despite high-decision costs, implementation costs are much lower, because of policy compliance [24,25]. Examples of cooperation include the policy network in the European context, which is based on corporatism culture. However, based on market-centered governance, these practitioners cooperate with those from the issue network. Therefore, we ask, what is the special form of governance in government-centered governance? First, we investigate collaborative governance as network governance before examining hegemonic governance.

\subsection{Collaborative Governance}

One solution to the issues in Korea is new governance, which is based on a network that considers the diversity of civil society. Network governance can be defined as a "collaborative process to develop a new socio-political order through civil society centered networking with governments and markets" [8]. Thus, the term "collaborative governance" can be used because "governance is a collaborative process" [8]. The terms, collaborative governance and network governance, can be used interchangeably [8].

In addition, network governance is assumed to be civil-society-centered as civil society plays an equilibrium role among governments, markets, and civil society [8]. If civil society represents a powerful and mature role in governance, then civil-society-centered governance can work effectively [26]. If the equilibrium between the government and civil society is broken and unbalanced, this causes conflict and problems rather than participation and collaboration [26]. If network governance does not work, it could return to government-centered governance or market-centered governance [8]. Thus, the term "collaborative governance" can be used assuming that governance is a collaborative process among at least three diverse actors [8].

What is collaborative governance? Ansell and Gash (2008) suggest that collaborative governance is a form of governance with two-way communication and the authority to transform an adversarial relationship into a cooperative one [27]. Thus, collaborative governance is "a type of governance in which public and private actors work collectively in distinctive ways, using particular processes, to establish laws and rules for the provision of public goods" [27]. On the basis of 137 case analyses, Ansell and Gash (2008) suggest the following definition and the six criteria for collaborative governance: 
"A governing arrangement where one or more public agencies directly engage non-state stakeholders in a collective decision-making process that is formal, consensus-oriented, and deliberative and that aims to make or implement public policy or manage public programs or assets". [27]

"This definition stresses six important criteria: (1) The forum is initiated by public agencies or institutions, (2) participants in the forum include non-state actors, (3) participants engage directly in decision making and are not merely "consulted" by public agencies, (4) the forum is formally organized and meets collectively, (5) the forum aims to make decisions by consensus (even if consensus is not achieved in practice), and (6) the focus of collaboration is on public policy or public management". [27]

Specifically, "collaborative" can be defined as an autonomous, individual interaction process for creating new public value beyond the boundaries and policies of organizations [28]. Also, collaborative can be categorized in different ways; it can range from a loose, informal, and temporary type of network to an integrated unitary organization [29]. This implies that many different types of collaborations can be formed and these different types of collaboration demonstrate the possible forms of collaboration in local government [8].

\subsubsection{Limitations of Collaborative Governance: From Collaborative Governance to Hegemonic} Governance

Collaborative governance may not resolve the problem in governance regarding the lack of trust, although it defines the norm of social relations and establishes a behavioral method in extremely complex and fragmented societies [8]. In particular, when stakeholders have insufficient experience, the problems become bigger. Furthermore, the governance approach does not consider cooperation and coordination costs. To form a network, actors usually go through brokers and coordinators. Otherwise, actors themselves must find a way to coordinate and cooperate. If a problem occurs, no official coordinator or judge is available to resolve the issues. Thus, it is not easy to compromise on solutions. Thus, we need to consider another type of governance in case collaborative governance does not work.

\subsubsection{Hegemonic Governing Process}

The concept of the collaborative governance structure may need to be modified to explain certain South Korean cases. To understand South Korean governance in local areas with dualism and Jeongish citizenship, the concept of hegemonic governance must also be understood. Hegemonic governance explains why both collaboration and confrontation coexist [8]. As Davies [30] suggested, in hegemonic governance, governments pursue both consent and coercion by mobilizing civil societies to realize the interests formed by the government (central and local governments) and civil society [31].

The hegemonic governing process is also an alternative way of describing the Korean NGO position in relation to local governments. This approach is associated with the government-centered governance mentioned above. Collaborative governance is limited because it assumes a double collaborative process between inter-local governments and intra-local governance with civil society [8]. However, collaborative governance stresses a strategy based on competition and antagonism rather than confidence and reciprocity [8]. Furthermore, collaborative governance should employ structural environment analyses and practical procedures and processes, but normativity in collaborative governance is not fully implemented in South Korea; it rather tends to mobilize in the justification of neo-liberal strategies [8].

Thus, the hegemonic governing process can overcome the limitations of collaborative governance [8]. This means that collaborative governance is no longer structured and operates based on mutual trust and collaboration; instead, it is structured and operates based on strategic motivation, participation, and mutual competition [8]. This is because collaborative governance can be understood as government and civil society operating together, which is similar to the hegemonic 
governing process [8]. Collaborative governance can be seen as polycentral governance, which is created by self-regulating entities [8]. However, this polycentral governance is not guaranteed but can be maintained by practical struggles in hegemonic governance [8]. In addition, inter-local collaborative governance needs economic complementarity and infrastructure construction to boost the connectivity between local governments because it assumes a material basis in addition to a discursive process [8]. Therefore, the structure and operation of collaborative governance in South Korea can be considered hegemonic governance that causes consent and resistance in the government and civil society [8].

Thus, in South Korea, the background and concepts discussed here apply to water resource governance. Based on this political environment, we can suggest some characteristics of Korean NGOs and apply these concepts to the Daegu-Gumi conflict. Based on the theory and background mentioned above, we describe how South Korea dualism results in the deformation of collaborative governance into hegemonic governance based on dualism and Jeongish citizenship.

\subsection{Dualism and Jeongish Citizenship in Korean Society}

Dualism is the main concept to understand in relation to understanding South Korean society. Korean civil society has the unique characteristics of being a dual civil society with weak local membership, low social capital, and "national-democratic and moral-political enhancement of common citizenship" [32]. Kim (2010: 434) explains that dualism, in this case, relates to "the paucity of social capital in everyday life and the plethora of collective political actions in the national civil society." This is because local voluntary associations have been curbed by the government and Confucian culture [32]. Korean civil society activity is usually based on large professional advocacy groups in Seoul, rather than in local areas [32]. They are also characterized as being part of a national alliance emphasizing public goods or the common interest [32]. The Korean government's attitude toward NGOs is still reluctant [33] and NGOs tend to depend on the government rather than on partnership [34]. One of the main differences between the United States and South Korea is that U.S. advocacy civil society is a type of a pluralist model with "nationally franchised membership organizations" aiming to boost members' interests via lobbying political parties [32]. However, despite its weak local membership and low social capital, South Korean civil society is made up of "national alliances of a multitude of large and small civic groups" that support national democracy and moral politics for citizens, and this is called dual civil society [32]. This is one of the impediments to an authentic Korean democratization process [32]. To understand dualism, it is necessary to understand the concept of Confucian via Jeongish citizenship.

Despite the many NGOs in Seoul, the Korean local civil societies have weak social capital and foundations because of Confucian and Jeongish citizenship. Kim (2010: 434) calls the Korean style of civil society based on Confucius and Jeong as the "Korean version of Confucian civil society." Korea has maintained an authentic form of Confucian society $[35,36]$ and even still practices Confucian customs [32]. Without understanding Confucian culture, it is not practical to apply a Western Christian view on the Korean situation. Confucian culture stresses inter-personal relationships and faithfulness (or being Jeongish) and Confucian social relations are modeled after extended family relations [32]. Thus, it is necessary to consider the Confucian social structure and Jeong to understand Korean civil society. From one perspective, Jeongish citizenship is good for unity and creating a "family affectionate sentiment" [32]. However, it can prevent people from having diverse opinions due to Jeong. However, even though Jeongish citizenship is helpful for understanding Korean civil society, it has limitations, as it is not easy to criticize others' faults when one holds Jeongish citizenship. Especially in local areas, the connections within societies are closer, which makes it difficult to criticize other citizens. In addition, it hinders the development of diverse civil societies due to a lack of participation and dualism. As a result, this dual civil society from Confucian and Jeongish culture is problematic when attempting to consolidate authentic democracy [32], despite its positive influence on unity. It is one of the unique aspects of Korean culture that helps explain Korean governance.

Thus, dualism and Jeongish citizenship help to describe democratic collective self-government and the common citizenship of South Korean Confucian civil society, which is distinct from the West 
and its moral individualism [32]. However, dualism and Jeongish citizenship could prevent South Korean civil society from establishing a strong opposition to local government because they are so closely related. To make matters worse, the networks at the local level are close to each other, and they have insufficient experience in local governance and collaboration. This brings about weaker social capital and participation in South Korea local areas compared to the national arena.

\subsection{Research Design}

This case analysis is based on a single case of the repositioning of water intake sources. Among the many cases of water conflict, we focus on the most recent case that depicts the conflict between the City of Daegu and the City of Gumi, which has been discussed for a long time. During the conflict, the cities organized a collaborative governance approach to resolve the problems but failed to compromise. The main research topic is the application of dualism and Jeongish citizenship with Confucian culture to understand why collaborative governance did not work and why it was transformed into a hegemonic governance approach during this South Korean water conflict situation.

To analyze the case, following the chain of evidence, we collected data using interview data from other research [31] and archival data, such as books, journals, and news articles. The data were related to the repositioning of water intake sources between the City of Daegu and the City of Gumi. The geographical boundaries of this case study are the central government and Gyeongsang Province, which includes the City of Daegu and the City of Gumi.

Ansell and Gash (2008: 550) suggested a model of collaborative governance, based on four main concepts: "starting conditions, institutional design, leadership, and collaborative process" [27]. They aimed to test this framework to establish a contingency theory as a hypothesis [27]. Depending on the historical situation, an imbalance between stakeholders can sometimes facilitate participation. With basic protocols and rules, stakeholders form in a collaborative governance environment and can achieve their goals. During this process, the leadership needs to facilitate face-to-face dialogue, build trust, enhance commitment to share understanding, and enhance mutual gains. These actions can bring about small wins, which encourage a virtuous cycle among stakeholders. In the end, after a repetitive, collaborative process, they can produce their desired outcome.

Using cultural perspectives and governance theory, we investigated the following sub-questions: What was the main issue between the two cities? How did the governance of cities and civil societies attempt to resolve this conflict? What did civil society do? Why did they fail to compromise? Then, we analyze the data to reveal the inappropriateness of collaborative governance. In conclusion, this study demonstrates how dualism and Jeongish citizenship in the South Korean context influenced collaborative governance and was transformed into hegemonic governance, which are represented in Figure 1. 

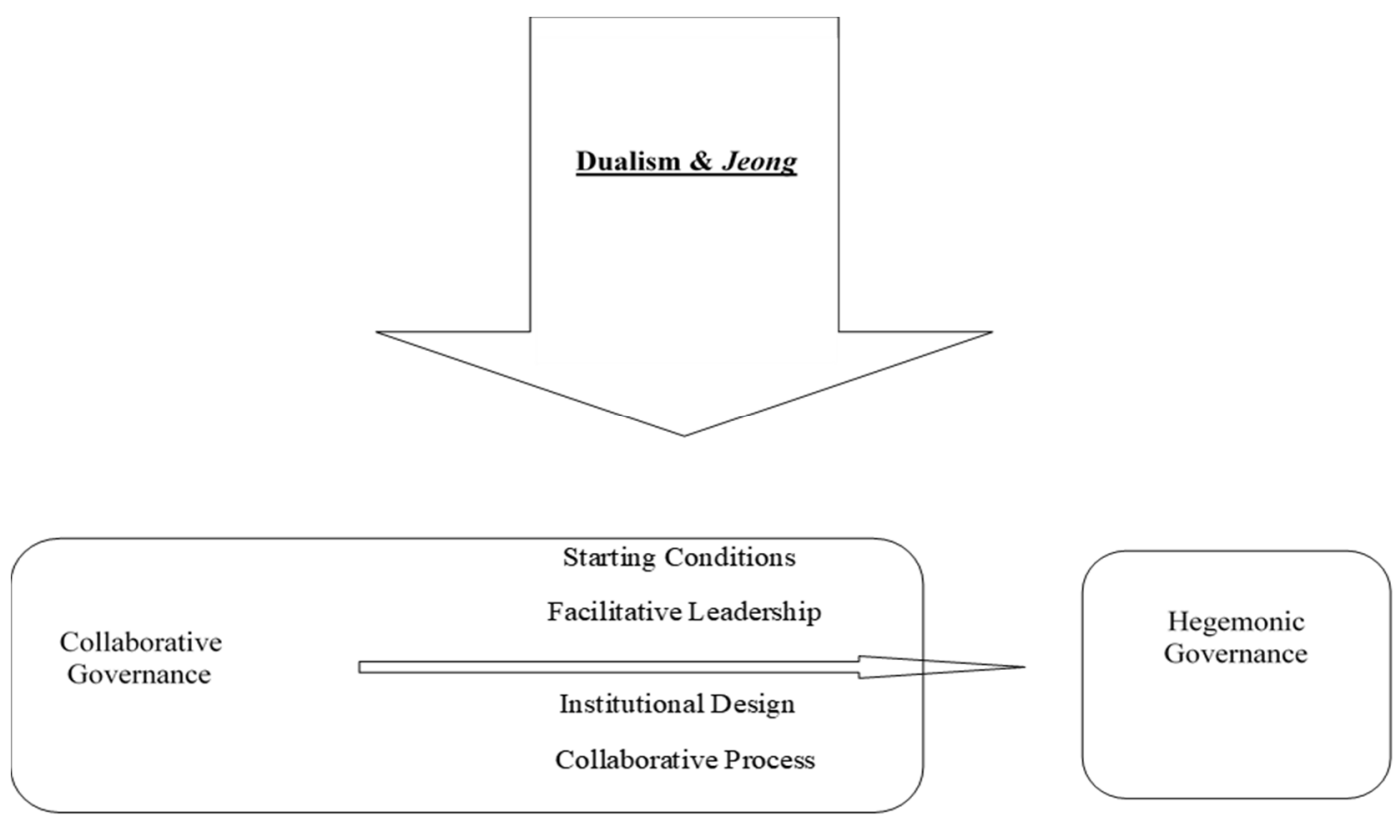

Figure 1. Conceptual framework for Daegu-Gumi water intake source conflict.

2.5. Conflict on the Relocation of the Water Intake Plant: Water Resource Governance in Daegu-Gumi Water Intake Source Conflict

Local autonomous governments have faced many different conflicts. Conflict over water sources, in particular, is one of the most critical forms of conflict between local autonomous governments in South Korea [37]. The conflict on the location of water intake facilities (tap water, dams, water intake stations, and so on) between two regions has been a long-standing issue. While the City of Daegu has attempted to find new water intake sources, specifically from the City of Gumi, the City of Gumi disagrees with this due to water shortage and quality issues [38].

Although the City of Daegu already had a sufficient water supply, the City of Daegu wanted to increase the supply levels of high-quality water [31]. The Nakdong River phenol contamination accident in 1991 and the hydrofluoric acid spill accident in 2012 motivated the people of Daegu to request better water intake sources. After many attempts, that included searching for new water intakes sources, preliminary feasibility tests, and the publication of a "Review Report on Clean Water Supply Planning to the Gyeongbuk-Daegu Area," hereafter referred to as the Review Report, [31] to resolve this issue, the mayor of the City of Gumi held a media interview where he suggested that creating a citizens and bureaucrats commission [39] and suspending the pre-process for the relocation of the water intake source was necessary [40].

From March 2015 to June 2016, the City of Daegu and the City of Gumi formed the commission (the Daegu Water Intake Source Daegu-Gumi Citizens and Bureaucrats Commission-hereafter, the Daegu-Gumi Water Commission) with ten members from each city that included bureaucrats and citizens (including scholars, experts, and bureaucrats). The commission held eight more meetings until June 2016, see Table 1. 
Table 1. Timeline of Daegu-Gumi Water Commission.

\begin{tabular}{cl}
\hline \multicolumn{1}{c}{ Date } & \multicolumn{1}{c}{ Content } \\
\hline 17 March 2015 & - Agreement on the venue, the election of a chief of the commission, and other operations [31]. \\
\hline 9 April 2015 & $\begin{array}{l}\text { - Review Report of the Ministry of Land, Infrastructure, and Transport (MOLIT) is verified [31]. } \\
\text { - Compromise reached for the City of Daegu to examine the conflicting sections [31]. }\end{array}$ \\
\hline 23 May 2015 & - The decision to visit and refer to other domestic conflicting areas in South Korea [31]. \\
\hline 22 July 2015 & $\begin{array}{l}\text { - Debate on the validity of the MOLIT Review Report [31]. } \\
\text { 3 The City of Gumi distrusts the MOLIT Review Report [31]. }\end{array}$ \\
\hline 14 January 2016 [41] & $\begin{array}{l}\text { - Debate on the validity of the MOLIT Review Report [31]. } \\
\text { had the following questions: How would the plan deal with water problems in the case of water } \\
\text { quality accidents?; how does the plan manage water from other dams? (Yeongcheon Dam); how } \\
\text { does the plan develop the whole of the Nakdong River? [42]. From these questions, it was clear } \\
\text { that Gumi's position was almost the same as a rejection [41]. }\end{array}$ \\
\hline Engineering and Building Technology [31]. \\
\hline 29 March 2016 [43]
\end{tabular}

Although they agreed with the agenda, the varying starting intentions led to the failure of the compromise. At the second meeting, they agreed to double-verify the Review Report for the benefit of both sides [31]. By verifying the Review Report, the City of Daegu could endorse the relocation of the water intake sources, while the City of Gumi could rebut the Review Report and attempt to block the move [31]. On 3 September 2015, even after the presentation of the author of the report from the Korea Institute of Civil Engineering and Building Technology, the participants failed to compromise and instead the two cities reconfirmed their opinions [46]. However, they agreed to create another small commission to investigate the diverse issues [46]. Additionally, the City of Daegu attempted to find alternative ways without Gumi [46]. Kwon Young-jin, the mayor of Daegu, said, "I will search the most appropriate method for collaboration with the city of Gumi; suppressing an emotional response to develop a common understanding for moving the water intake sources, I will collaborate with the National Assembly and civil society" [46].

A 2015 survey of 1,000 Daegu citizens demonstrated that 73.7\% agreed with moving the water intake sources, and $81.7 \%$ said that the sources should be moved to the upper Gumi National Industry Complex [46]. Yoon Jong-Ho, the chief of the Gumi members of the Daegu-Gumi Water Commission said, "Despite the time consumption, we need to verify the validity of moving the water intake sources from the beginning, and based on this, I will continue to negotiate with the City of Daegu" [46].

Even after Mayor Kwon set a New Year's resolution to resolve the water intake source problems for the City of Daegu, the problem-solving process did not advance [41]. On 1 June 2016, at the eighth meeting, the decision of a proposal at the seventh meeting (the request of the City of Daegu that the MOLIT verifies whether relocating the Daegu water intake sources would cause reductions in the quantity and quality of water around the Gumi area) was delayed [44]. In the end, on 20 October 2016, facing a stalemate, the Daegu Metropolitan Council created specific committees to resolve the problem of moving the Daegu water intake sources [47]. This demonstrated that the Daegu-Gumi Water Commission appeared to be more of a tool for delaying rather than solving the conflict or finding alternatives [31]. We explain this along with the theory mentioned above in the Korean context in the next section. 


\section{Application of the Theory to the Case Study}

Based on the background of a water intake source conflict, we analyzed Korean water resource governance. South Korean civil societies have low social capital, and an overwhelming portion of the political action takes place at the national level. The authorizations required from ministries for establishing NGOs induce a poor environment for civil society compared to Western NGOs because the approval process prevents people from freely establishing NGOs. As a result, the lack of power and experience in local civil society has led to the malfunction of collaborative governance, and it has transformed into hegemonic governance. The lack of experience means that local leaders do not have the capacity to deal with conflicts or negotiate the problems that they face. In particular, civil society has failed to ameliorate the conflict between the City of Daegu and the City of Gumi.

The establishment and implementation of the Daegu-Gumi Water Commission by the City of Daegu and the City of Gumi is an example of collaborative governance, at least superficially. However, it quickly transformed into hegemonic governance [31] because of dualism and Jeongish citizenship. Consequently, the Daegu-Gumi Water Commission is more hegemonic governance than collaborative governance.

\subsection{From Collaborative Governance to Hegemonic Governance because of Dualism and Jeongish Citizenship}

When the two cities began to meet to achieve their goals, they applied collaborative governance rather than an adversarial relationship. Superficially, the Daegu-Gumi Water Commission appears to be a form of collaborative governance when the six criteria established by Ansell and Gash are applied (2008: 544-545): (1) The commission was initiated because of a Review Report published by a public agency from the central government, the Ministry of Land, Infrastructure, and Transport (MOLIT); (2) the participants included two academic experts, five members from civil society, and citizens (non-state actors); (3) the members of the commission influenced the decision-making directly; (4) the commission was formally organized; (5) the decisions required consensus, which is why the commission struggled to make decisions; and (6) the purpose of the commission was to collaborate on public policy or public management of the water intake source issue.

\subsubsection{Starting Conditions}

In this case, the two cities faced deadlock in the conflict that facilitated collaborative governance not only because both are highly interdependent [48] (Futrell, 2003), but also because the deadlock was costly for both parties [27]. This is because the water quality problem has been a key issue for both cities since 1991 and after the Nakdong River phenol contamination accident. Since then, the City of Daegu has been pursuing new water intake resources at the upper Gumi-Inseon Bridge, while the city of Gumi has been seeking to relocate the new water intake sources at the Andong Dam [31]. The City of Gumi organized the Pan-Gumi City Citizen Anti-Water Intake Plant Committee and demonstrated its anti-water-intake-plant intention via this group's movements, which included holding a rally with relevant organizations to demand alternative resolutions [31].

From the perspective of dualism and Jeongish citizenship, there was dissonance in the collaborative governance relationship. First, in reality, the City of Gumi did not have an equal relationship with the City of Daegu, especially considering that using its predominant administration and finance strengths (from an interviewee from Gumi civil society who participated in the commission), Daegu pushed for the relocation of the water intake sources [31]. This recognized asymmetric power $[49,50]$ motivated Gumi to participate in the Daegu-Gumi Water Commission. However, by suggesting that the commission is established, the City of Gumi could establish an equal relationship with the City of Daegu by having the same number of members on the commission [31]. Second, according to dualism and the lack of participation, apart from specific stakeholders, such as people living around the water intake source and around the industrial complex (from an interviewee from Gumi civil society who participated in the commission), the attitude of most citizens was indifferent [31]. Third, specifying 
that the commission was employed as a strategy for the City of Gumi to block the relocation of the water intake source, does not fit with the aim of collaborative governance [8]. Daegu's agreement to participate in the commission was passive (from an interviewee, an expert from Daegu, who participated in the commission), and they were simply following Gumi's suggestion [31]. Furthermore, the two cities' agreement to participate in the commission was an attempt to avoid blame and to find a breakthrough [31].

\subsubsection{Facilitative Leadership}

In the case of imbalanced power and resources in a highly antagonistic situation, leadership is especially important [27]. However, in reality, the role of the leader of the Daegu-Gumi Water Commission was constrained (from an interviewee, an expert from Daegu, who participated in the commission and from an interviewee from Gumi civil society who participated in the commission), as the role of the chairperson was not to facilitate communication and compromise [31]. Furthermore, although the central government was directly involved in the process, it demonstrated bias in favor of the City of Daegu when it backed the Review Report, which supported the Daegu side [31].

Following Jeongish culture, facilitative leadership should comprise with local and national leaders. However, the president and senior politicians were insufficiently involved with this issue. If possible, the governor of Gyeongsang Province could have helped address these conflicting issues. However, they might have been reluctant because being seen to take a side during the conflict might have compromised the votes they required for reelection.

\subsubsection{Institutional Design}

Institutional design in collaborative governance establishes "the basic protocols and ground rules for collaboration," such as broad and active inclusive participation, and "clear ground rules and process transparency" along with a deadline [27,51]. Although the Daegu-Gumi Water Commission had a schedule, a listed venue, a period of operation, and the number of members on the commission was fair, the commission did not specify the detailed meeting operations or the status of the agreement [31]. From the perspective of Jeongish culture, they are not used to specifying their operations publically as they do with their families. Furthermore, like Jeongish culture, considering the local government bureaucrats' one-way communication, the role of the participants of the committee was hierarchical and not complete participatory governance [13,17] or equal [31]; the people who were eligible for compensation after the relocation of the new water intake sources were excluded (from an interviewee, a Gumi citizen, who did not participate in the commission) from the Daegu-Gumi Water Commission [31]. This raised suspicions regarding the authenticity of the Daegu-Gumi Water Commission and reflected hegemonic governance. These problems derived from the lack of participation and problems stemming from dualism.

The lack of information resulted in distortion, misunderstanding, prejudices, and constraints on collaboration among stakeholders [31]. The Review Report did not provide transparent information and was not publicly released [31]. Furthermore, both cities were reluctant to reveal their information and tended to keep useful information to themselves [31]. Additionally, there was conflict (from an interviewee, an expert from Daegu, who participated in the commission) about whether to reveal the convention results or not [31]. One factor that caused this could be the weaker and smaller media in Gumi that had less power than the media in Daegu [31].

As a result, along with the lack of citizen participation at the local level, the commission was almost completely mobilized as an implication of Jeongish citizenship by the force of city government, which boosts the idea that it had reverted to hegemonic governance. Although some people join and pay membership dues to advocacy nonprofits for fighting for public policy, most citizens are still not interested in the issue of moving Daegu's water intake sources [31]. This reflects dualism, Jeongish citizenship, and the fact that civil society is employed by the local government as an instrument when they are associated with a government purpose. For instance, Yang Myung-Mo, the chief Daegu 
member of the Daegu-Gumi Water Commission, said that the "Daegu-Gumi Water Commission should not be employed for delaying rather than implementing the project. We have to move water intake sources when the government has an interest in this" [46]. This demonstrates that the creation of the Daegu-Gumi Water Commission was mostly motivated by the city government [31] rather than by civil society.

\subsubsection{Collaborative Process}

In a cyclical collaborative process, direct face-to-face dialogue with commitment is necessary for mutual gain [27]. Additionally, negotiating and building trust among stakeholders are both important [50-58]. Building trust is necessary, but it is difficult to cultivate, especially where there is an antagonistic prehistory among the stakeholders [55]. Stakeholders should share an understanding of what they want to achieve [57] and an agreement on a definition of the problems [59-61]. In the end, collaboration achieves small wins [62-65] and boosts a virtuous cycle of trust and commitment $[58,66]$.

From the perspective of dualism and Jeongish citizenship, we can see that both collaboration and confrontation coexisted in the Daegu-Gumi Water Commission, similar to a family. Although they began to seek new water intake sources in light of the recommendations of the central government, they sometimes conflicted and collaborated depending on their situations. In the commission process, we can see the inappropriateness of collaborative governance in this case because there were so many conflicts between the cities. Thus, considering dualism in the context of the Korean culture, we can assert the influence of hegemonic governance rather than collaborative governance as follows.

First, in this case, the two cities had insufficient time to build trust. Meeting several times was insufficient because they are not families sharing Jeong. If the Daegu-Gumi Water Commission was maintained for a long time, spending time and overcoming good and bad memories and uncertainties like a family, meeting several times might have been sufficient to revitalize their trust. They needed to devote more time to meeting and do so with more sincerity to build trust for better collaborative governance.

Second, both cities pursued both consent and coercion by mobilizing civil society to realize the interests formed by governments (central and local governments) and civil society [31] and using Jeongish citizenship caused them to swallow or endure criticisms. The members of civil society that participated in the Daegu-Gumi Water Commission seemed to be especially mobilized by local governments to support each city's stance. Although the stakeholders appeared to be sharing the definitions of the problems, they did not share an understanding of what they wanted to achieve. For example, most Gumi members of the Daegu-Gumi Water Commission (from an interviewee, an expert from Daegu, who participated in the commission) were from the Pan-Gumi City Citizen Anti-Water Intake Plant Committee [31]. Additionally, the Daegu members of the commission supported the City of Daegu [31]. The civil society participants of the Daegu-Gumi Water Commission from the City of Daegu agreed with Daegu, and supported the relocation of water intake sources from the City of Gumi (At the same time, the excluded civil society Daegu groups stressed the Nakdong River preservation rather than moving the water intake sources (from an interviewee from Daegu civil society who did not participated in the commission)) [31], while the civil society representatives from the City of Gumi agreed with Gumi (The excluded civil society Gumi groups preferred sharing Gumi riverside filtered water to the relocation of the water intake sources for Daegu, Gumi, and future generations (from an interviewee from Gumi civil society who did not participate in the Commission)) [31], and opposed the relocation of water intake sources from the City of Gumi. Furthermore, local governments and local civil societies are closely connected without systematic arguments and collaboration. This causes a lack of experience in dealing with problems in local areas. Civil societies in local areas have insufficient participation from citizens, leading to a lack of criticism of local governments.

This reflected the Jeongish culture in South Korea and led to hegemonic governance, preventing real collaborative governance. Different opinion groups should have been allowed to participate in the Daegu-Gumi Water Commission for better collaborative governance. 
Figure 2 summarizes how Jeongish citizenship and dualism influenced the Daegu-Gumi Water Commission. As mentioned, even at the beginning stages, their basic stance was different. Without special interventions and concerns from national NGOs, South Korean civil societies are passive because of dualism. Similarly, unlike national civil societies, local civil societies do not have sufficient power and experience to deal with local problems. National civil societies confront many conflicts, and collaboration among government and civil societies is insufficient. However, on the local level, it is very hard to see how civil society can be a key player in addressing conflict when they only support the government. The collaboration between governments and civil society is almost nonexistent due to the Jeongish relationship among them that includes only supportive local NGOs and excludes unsupportive NGOs. This is useful to prevent large conflicts retaining constancy and unity in local areas. However, this causes civil society to follow the lead of local governments. Moreover, the central government or local governance leadership is insufficient for resolving the conflict [67]. Rather the central government sided with the City of Daegu and this deformed the superficial collaborative governance and transformed it into hegemonic governance.

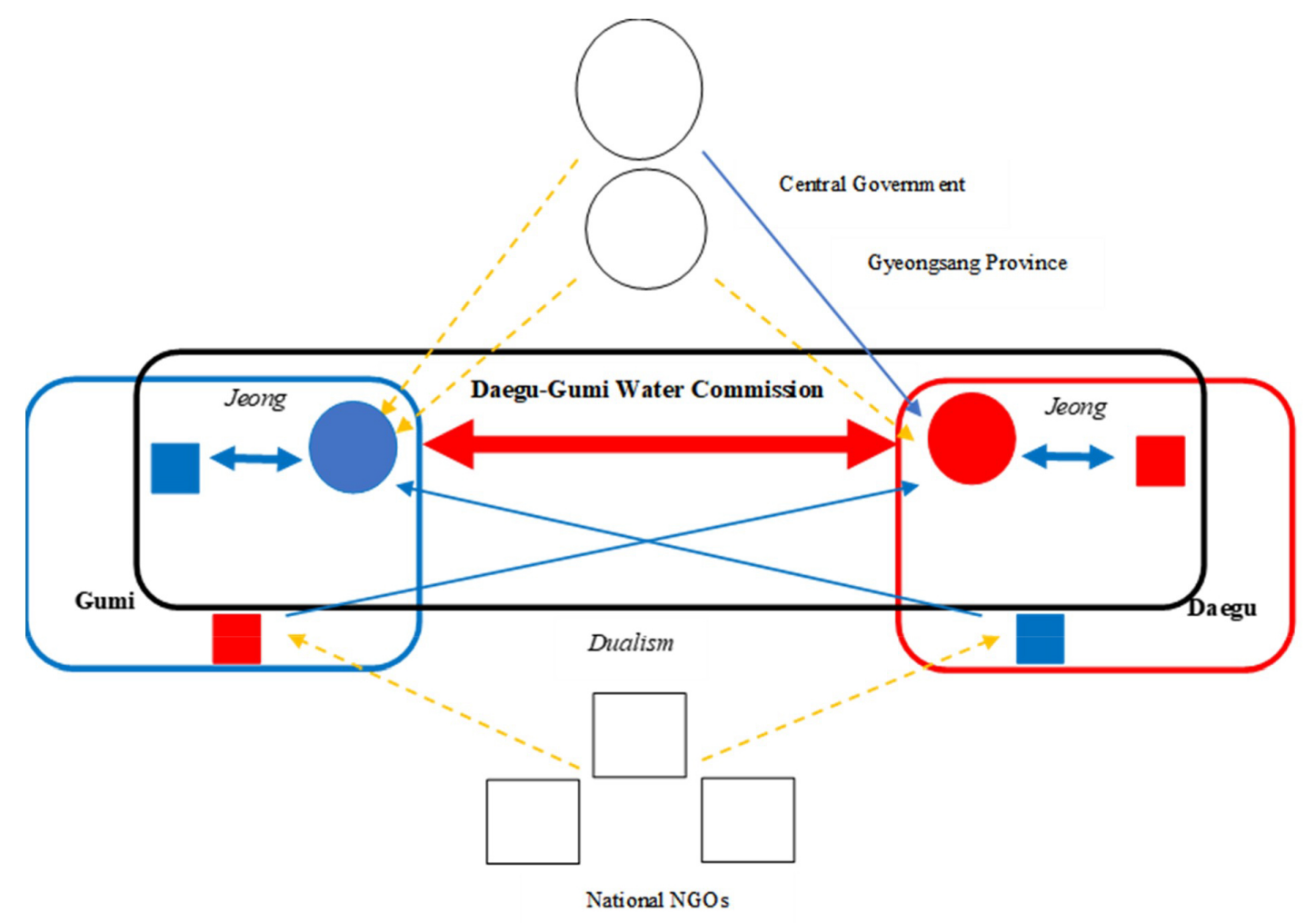

\section{$\underline{\text { Legend }}$}

$\underline{\text { Weak (or indifferent) Relationship }}$

$\longrightarrow \quad$ Direction of Relationship (Red: negative, Blue: positive)

$\square$ NGOs, Citizens

Governments (Relationship (Red: Gumi, Blue: Daegu)

Figure 2. Mapping the actors in the Daegu-Gumi Water Commission. 
Ultimately, they failed to reach a consensus, and the two cities' alternative resolutions were separated. The City of Daegu wanted the central government to actively intervene (from an interviewee with a Daegu expert who participated in the commission) by compensating Gumi because of Daegu's limited resources [31]. Meanwhile, the City of Gumi asked to test the necessity of moving the water intake sources, and in the long term, the city wanted to co-manage the mid-Nakdong River (from an interviewee from Gumi civil society who participated in the commission) by regulating industrial factory placement and supervising water quality [31]. Furthermore, when reviewing the timetable of the Daegu-Gumi Water Commission, see Table 1, it is hard to find a sufficient consensus. The commission achieved small wins, such as the agreement of a venue, the election of a chief of the commission, and other operations [31]. However, the results were too trivial to boost trust in their ability to resolve problems. This confirms that small wins are sometimes insufficient when each party has a more ambitious target to achieve [68]. Finally, they failed to reach a consensus rather than share their understanding.

\section{Conclusions}

In South Korea, dualism and Jeongish citizenship cause collaborative governance to function poorly on the local level because of a lack of participation and Confucian culture. During the conflict on the relocation of the water intake sources between Daegu and Gumi, we can see that the dissonance between the culture and the social system caused an unexpected result. Although the establishment of the Daegu-Gumi Water Commission made an effort to follow the ideal path-collaborative governance-eventually, the commission transformed into practicing hegemonic governance.

Finally, the superficial collaborative governance established by the Daegu-Gumi Water Commission failed to reach a consensus. Rather, it was transformed into hegemonic governance. In hegemonic governance, local governance mobilizes civil society to reach a consensus and to realize the interests formed by the local government. This is due to the dualism that creates weak local membership, participation, experience, and social capital on the local level; South Korean civil societies have insufficient power and experience to influence or compromise with local governments. Furthermore, organizations with different opinions could not participate and spread their ideas due to Jeongish culture. The Daegu-Gumi Water Commission failed to reach a consensus and did not realize a truly collaborative governance process because of polarized stances, weak facilitative leadership, and clumsy institutional design, along with blurred information and rules.

Thus, it is clear that collaborative governance is not a panacea and needs to be adjusted in the Korean setting. Without consideration of the embedded Korean culture-dualism and Jeongish citizenship with Confucian culture-implementing Western-style collaborative governance will never be easy; rather, collaborative governance tends to become transformed into hegemonic governance.

\subsection{Contributions}

This study demonstrates the importance of policy decision making and implementation beyond agenda setting. Despite many disastrous moments such as the Nakdong River phenol contamination accident, the hydrofluoric acid spill accident in 2012, and the like, agenda setting still occurred. However, without collaboration, the agenda could not be successfully implemented. Thus, we need to think about how to boost successful polity implementation through collaborative governance in terms of management and policy perspectives.

\subsection{Lessons Learned}

The transformation of collaborative governance into hegemonic governance does not always imply undesirable results. Furthermore, the Daegu-Gumi Water Commission is still active, which means the commission still has an opportunity to achieve its goal in the future. Without the collaboration of the Daegu-Gumi Water Commission, the conflict between Daegu and Gumi would become more severe without any resolution because neither entity has an official method for meeting and discussing this 
issue. The current hegemonic governance forms a foundation for future entrepreneur leadership to overcome the stalemate in the parallel, highly antagonistic situation [27], and to facilitate negotiation. Although these resolutions do not guarantee that an optimal situation will develop, we hope the Daegu-Gumi Water Commission can resolve the problem beyond Kaldor-Hicks Efficiency [69] by compensating the sacrificed entities.

\subsection{Implications for Sustainability}

As water shortages are one of the main issues addressed by sustainability, we can extract the implications of failed or successful sustainability from water shortage crises. The decisions of local governments cannot guarantee success, so we need to encourage collaboration between discrete entities [22]. However, we need to keep in mind that collaborative governance is not a panacea. Collaborative governance is applicable between local and central governments, to resolve their problems through horizontal cooperation among diverse organizations $[70,71]$, rather than through competition among local governments and control of local governments by central governments [8]. This collaborative governance can be employed to deal with social space problems and to provide public goods and services [72]. However, collaborative governance cannot always guarantee promising results [27]. That is why Ansell and Gash (2008) asked scholars and practitioners to verify the context for collaborative governance to succeed.

Therefore, we need to develop and facilitate citizen participation and their authority for representativeness. In collaborative governance between regions, although local governments and public agencies lead, the participation of non-government actors is limited or ignored in South Korea $[8,73]$ and some other countries. When the conflict between local governments represents a regional conflict, the interest relation of both local governments and civil society is identified, and civil society representatives should be considered to represent their local governments [8]. This is associated with the solution of how to overcome dualism and Jeongish citizenship.

\subsection{Further Study}

Understanding unsuccessful cases on the basis of theory and practice contributes to a better understanding of the future of collaborative governance and water conflicts in South Korea and around the world. As a result, this study will expand our understanding of the problems related to governance in order to formulate better governance as adaptive governance [10]. Furthermore, should this type of issue arise again, this study should contribute to resolving these problems. Therefore, these results should be developed to investigate how problems can be overcome by establishing remedies to prevent the occurrence of hegemonic governance. As a form of alternative governance, adaptive governance includes collaboration, flexibility, and learning-based institutions [10], or collaborative platforms that can address problems on a wider scale. A collaborative platform can deal with larger scale problems than collaborative governance [74]. This form of governance needs to be discussed in future studies. We hope this study paves the way for sustainable resolutions between local governments and between countries involved in international conflicts in the future. However, we need to keep in mind that governance is not a panacea and we need to continue to fix and modify its problems.

Author Contributions: K.W.C. designed this research and analyzed data sets; K.J. contributed to elaborating theoretical and policy implications as well as structuring of this research.

Funding: National Research Foundation of Korea: NRF-2016S1A3A2924832.

Acknowledgments: This research was supported by the Ministry of Education of the Republic of Korea and the National Research Foundation of Korea (NRF-2016S1A3A2924832). We also appreciate the support from the Brain Korea 21 Plus in the Department of Public Administration at Korea University.

Conflicts of Interest: The authors declare no conflict of interest. 


\section{References}

1. Reig, P.; Maddocks, A.; Gassert, F. World's 36 Most Water-Stressed Countries. World Resources Institute. 12 December 2013. Available online: http:/ / www.wri.org/blog/2013/12/world\%E2\%80\%99s-36-most-waterstressed-countries (accessed on 1 September 2016).

2. Ministry of Land, Infrastructure, and Transport (MOLIT) \& K-Water. Water and Future; MOLIT \& K-Water: South Korea, 2016.

3. Kim, J.Y.; Kwak, M.S. A Study on the Governance System in the Process of Foreign Advance of Water Resource Management; Korean Association of Governmental Studies (KAGOS): South Korea, 2015; Volume 3, pp. 38-60.

4. Cho, J.H. Water Shortage Grips Korean Peninsula. Korea Herald. 30 March 2010. Available online: http:/ / www.koreaherald.com/view.php?ud=20090323000074 (accessed on 1 September 2016).

5. Kwon, K.D.; Yim, J.B.; Chang, W.Y. The Analysis of Intergovernmental Conflict Structure on the Use Water Resource. Korean Soc. Public Adm. 2004, 15, 551-580.

6. Blanco, I. Analysing Urban Governance Networks: Bringing Regime Theory Back In. Environ. Plan. C Gov. Policy 2013, 31, 276-291. [CrossRef]

7. Ostrom, E. Beyond Markets and States: Polycentric Governance of Complex Economic Systems. Am. Econ. Rev. 2009, 100, 641-672. [CrossRef]

8. Choi, B.D. Collaborative Governance and Development of the Yeongnam Region: A Conceptual Reconsideration. J. Korean Assoc. Reg. Geogr. 2015, 21, 427-449.

9. Swyngedouw, E. Governance Innovation and the Citizen: The Janus Face of Governance-Beyond-the-State. Urban Stud. 2005, 42, 1991-2006. [CrossRef]

10. Akamani, K. Adaptive water governance: Integrating the human dimensions into water resource governance. J. Contemp. Water Res. Educ. 2016, 158, 2-18. [CrossRef]

11. Lathem, K.W. The World Water Conferences at Mar del Plata. Can. Water Resour. J. 1977, 2, 74-81. [CrossRef]

12. Mirumachi, N.; Van Wyk, E. Cooperation at different scales: Challenges for local and international water resource governance in South Africa. Geogr. J. 2010, 176, 25-38. [CrossRef]

13. Brown, J. Assuming too much? Participatory water resource governance in South Africa. Geogr. J. 2011, 177, 171-185. [CrossRef] [PubMed]

14. Manzungu, E. Water for All: Improving Water Resource Governance in Southern Africa; International Institute for Environment and Development: London, UK, 2004.

15. K'akumu, O.A. Mainstreaming the participatory approach in water resource governance: The 2002 water law in Kenya. Development 2008, 51, 56-62. [CrossRef]

16. Kolavalli, S.; Kerr, J. Scaling up participatory watershed development in India. Dev. Chang. 2002, 33, $213-235$. [CrossRef]

17. Lennox, J.; Proctor, W.; Russell, S. Structuring stakeholder participation in New Zealand's water resource governance. Ecol. Econ. 2011, 70, 1381-1394. [CrossRef]

18. Rhodes, R.A.W. The New Governance: Governing without Government. Political Stud. 1996, XLIV, $652-667$. [CrossRef]

19. Rhodes, R.A.W. Understanding Governance: Ten Years On. Organ. Stud. 2007, 28. [CrossRef]

20. Ostrom, E. An Assessment of the Institutional Analysis and Development Framework. In Theories of the Policy Process; Sabatier, P., Ed.; University of California: Davis, CA, USA, 2007.

21. Jung, Y.D. Public Administration in a Current Nation; Bubmoonsa: Seoul, Korea, 2001.

22. Cho, K.W.; Brower, R.; Ahmad, M.S. Factors that Influence County Government Expenditures and Revenues: A Study of Florida County Governments. Lex Localis 2018, 16, 47-76. [CrossRef]

23. Kim, B.; Fording, R. Second-Order Devolution and Implementation of TANF in the U.S. States. State Politics Policy Q. 2010, 10, 341-367. [CrossRef]

24. Buchanan, J.M.; Tullock, G. The Calculus of Consent. Logical Foundations of Constitutional Democracy; University of Michigan: Ann Arbor, MI, USA, 1962.

25. Gamper, C.D.; Turcanu, C. Can public participation help managing risks from natural hazards? Saf. Sci. 2009, 47, 522-528. [CrossRef]

26. Joo, J.B.; Cho, S.J.; Kim, P.D.; Park, H.Y.; Ha, D.H. Strategies to Reinforce Collaborative Governance of Local Government; Korea Research Institute for Local Administration: Seoul, Korea, 2011. 
27. Ansell, C.; Gash, A. Collaborative Governance in Theory and Practice. J. Public Adm. Res. Theory 2008, 18, 543-571. [CrossRef]

28. Lee, M.S. Collaborative governance and publicness. Mod. Soc. Public Adm. 2010, 20, 23-53.

29. Sullivan, H.; Skelcher, C. Working across Boundaries: Collaboration in Public Services; Macmillan: Basingstoke, UK, 2002.

30. Davies, J.S. Challenging Governance Theory: From Networks to Hegemony; Policy Press University of Bristol: Bristol, UK, 2011.

31. Choi, B.D.; Chae, E.H.; Yang, M.J. Daegu metropolitan government's plan of relocation of water intake plant and collaborative governance between regions. J. Korean Assoc. Reg. Geogr. 2016, 22, 64-85.

32. Kim, S. On Korean Dual Civil Society: Thinking through Tocqueville and Confucius. Contemp. Political Theory 2010, 9, 434-457. [CrossRef]

33. Bidet, E. Explaining the Third Sector in South Korea. Volunt. Int. J. Volunt. Nonprofit Organ. 2002, 13, 131-147. [CrossRef]

34. Park, T.K. Government Policy Attitude on Nonprofit Organizations and Activities: A Comparative Study between Japan and Korea. In Proceedings of the First International Conference on Third Sector in Asia, Bangkok, Thailand, 20-22 November 1999.

35. Deuchler, M. The Confucian Transformation of Korea: A Study of Society and Ideology; Harvard University Press: Cambridge, MA, USA, 1992.

36. Koh, B. Confucianism in Contemporary Korea. In Confucian Traditions in East Asian Modernity: Moral Education and Economic Culture in Japan and the Four Mini-Dragons; Tu, W., Ed.; Harvard University Press: Cambridge, MA, USA, 1996.

37. Baek, D.I.; Choi, B.K.; Lee, K.I.; Kim, S.H.; Shim, G.S.; Kim, I.Y.; Woo, Y.S.; Lee, J.G.; Shin, M.J.; Yoo, E.J. No More Neighborhood. Muddy Fight among Local Autonomous Governments on the Water Resource and Name of Bridge. 2016. Available online: http://www.yonhapnews.co.kr/bulletin/2016/07/01/ 0200000000AKR20160701167800055.HTML?input=1195m (accessed on 15 October 2016).

38. Kim, H.T. [Contribution] Resolution for the Movement Daegu Water Intake Stations. Yeongnam Ilbo. 3 April 2014. Available online: http:/ / www.yeongnam.com/mnews/newsview.do?mode=newsView\&newskey= 20140403.010250802030001 (accessed on 15 October 2016).

39. Choi, S.H. Daegu-Gumi City will create a Daegu water intake source moving commission. Yonhap News. 17 February 2015. Available online: http://www.yonhapnews.co.kr/bulletin/2015/02/17/ 0200000000AKR20150217101551053.HTML (accessed on 22 October 2016).

40. "We want clean water, too": Moving Daegu Water Intake Sources Has Been in Conflict for Six Years. Yonhap News. 7 September 2015. Available online: http:/ / www.yonhapnews.co.kr/bulletin/2015/09/03/ 0200000000AKR20150903193700053.HTML (accessed on 15 October 2016).

41. Yoon, J.H.; Kim, B.J. [The Worst Draught, Water War] Neighborhoods in Youngnam Area is Worse than Strangers: Total Wars among Autonomous Entities. Herald Corporation. 21 February 2016. Available online: http:/ /biz.heraldcorp.com/common_prog/newsprint.php?ud=20160221000102 (accessed on 23 October 2016).

42. Kang, T.A. Drifting Un-Mun Dam's Water Supply Water to Ulsan is Unavoidable. Ulsan Maeil. 24 February 2016. Available online: http:/ / www.iusm.co.kr/news/articleView.html?idxno=645462 (accessed on 23 October 2016).

43. Daegu Water Intake Source Problems will be Discussed after General Election. Yeongnam Ilbo. 2 March 2016. Available online: http:/ / www.yeongnam.com/mnews/newsview.do?mode=newsView\&newskey= 20160302.010150748210001 (accessed on 23 October 2016).

44. Son, S.W. The Eighth Discussion of the Water Intake Source Moving was Unsuccessful. Yeongnam Ilbo. 2 June 2016. Available online: http:/ / www.yeongnam.com/mnews/newsview.do? mode=newsView\&newskey= 20160602.010080736440001 (accessed on 23 October 2016).

45. Kim, D.H. Daegu Water Intake Source Moving: Ninth Daegu-Gumi Citizens and Bureaucrats Commission Held. Youtong News. 18 November 2016. Available online: http:/ /www.youtongnews.com/bbs/board.php? bo_table=01_3\&wr_id=1368 (accessed on 21 October 2018).

46. Self-alternative Method is Necessary When Failing to Compromise: Daegu Water Intake Sources Moving with Gumi. Yonhap News. 28 August 2015. Available online: http://www.yonhapnews.co.kr/bulletin/2015/ 08/28/0200000000AKR20150828134400053.HTML (accessed on 23 October 2016). 
47. Kim, Y.T. Creating Special Committee for Daegu Water Intake Sources Moving. KyeongBuk Maeil. 20 October 2016. Available online: http://www.kbmaeil.com/news/articleView.html?idxno=396912 (accessed on 23 October 2016).

48. Futrell, R. Technical Adversarialism and Participatory Collaboration in the US Chemical Weapons Disposal Program. Sci. Technol. Hum. Values 2003, 28, 451-482. [CrossRef]

49. Gunton, T.I.; Day, J.C. The Theory and Practice of Collaborative Planning in Resource and Environmental Management. Environments 2003, 31, 5-19.

50. Imperial, M.T. Using Collaboration as a Governance Strategy: Lessons from Six Watershed Management Programs. Adm. Soc. 2005, 37, 281-320. [CrossRef]

51. Glasbergen, P.; Driessen, P.P. Interactive Planning of Infrastructure: The Changing Role of Dutch Project Management. Environ. Plan. C Gov. Policy 2005, 23, 263-277. [CrossRef]

52. Alexander, J.A.; Comfort, M.E.; Weiner, B.J. Governance in Public-Private Community Health Partnerships: A Survey of the Community Care Network: SM Demonstration Sites. Nonprofit Manag. Leadersh. 1998, 8, 311-332. [CrossRef]

53. Beierle, T.C.; Konisky, D.M. What Are We Gaining From Stakeholder Involvement? Observations from Environmental Planning in the Great Lakes. Environ. Plan. C Gov. Policy 2001, 19, 515-527. [CrossRef]

54. Brinkerhoff, D.W. Exploring State-Civil Society Collaboration: Policy Partnerships in Developing Countries. Nonprofit Volunt. Sect. Q. 1999, 28, 59-86. [CrossRef]

55. Murdock, B.S.; Wiessner, C.; Sexton, K. Stakeholder Participation in Voluntary Environmental Agreements: Analysis of 10 Project XL Case Studies. Sci. Technol. Hum. Values 2005, 30, 223-250. [CrossRef]

56. Short, C.; Winter, M. The Problem of Common Land: Towards Stakeholder Governance. J. Environ. Plan. Manag. 1999, 42, 613-630. [CrossRef]

57. Tett, L.; Crowther, J.; O'Hara, P. Collaborative Partnerships in Community Education. J. Educ. Policy 2003, 18, 37-51. [CrossRef]

58. Vangen, S.; Huxham, C. Nurturing Collaborative Relations: Building Trust in Interorganizational Collaboration. J. Appl. Behav. Sci. 2003, 39, 5-31. [CrossRef]

59. Bentrup, G. Evaluation of a Collaborative Model: A Case Study Analysis of Watershed Planning in the Intermountain West. Environ. Manag. 2001, 27, 739-748. [CrossRef]

60. North, P. Is There Space for Organisation from Below Within the UK Government's Action Zones? A test of 'Collaborative Planning. Urban Stud. 2000, 37, 1261-1278. [CrossRef]

61. Pahl-Wostl, C.; Hare, M. Processes of Social Learning in Integrated Resources Management. J. Community Appl. Soc. Psychol. 2004, 14, 193-206. [CrossRef]

62. Chrislip, D.D.; Larson, C.E. Collaborative Leadership: How Citizens and Civic Leaders Can Make a Difference; Jossey-Bass Inc. Pub.: San Francisco, CA, USA, 1994; Volume 24.

63. Roussos, S.T.; Fawcett, S.B. A Review of Collaborative Partnerships as a Strategy for Improving Community Health. Annu. Rev. Public Health 2000, 21, 369-402. [CrossRef] [PubMed]

64. Warner, J.F. More sustainable participation? Multi-stakeholder platforms for integrated catchment management. Water Resour. Dev. 2006, 22, 15-35. [CrossRef]

65. Weech-Maldonado, R.; Merrill, S.B. Building Partnership with the Community: Lessons from the Camden Health Improvement Learning Collaborative. J. Healthc. Manag. 2000, 45, 189-205. [CrossRef] [PubMed]

66. Rogers, T.; Howard-Pitney, B.; Feighery, E.C.; Altman, D.G.; Endres, J.M.; Roeseler, A.G. Characteristics and Participant Perceptions of Tobacco Control Coalitions in California. Health Educ. Res. 1993, 8, 345-357. [CrossRef]

67. Cho, K.W.; Yi, S.H.; Choi, S.O. Does Blake and Mouton's Managerial Grid Work? Int. Rev. Public Adm. 23, 103-118. [CrossRef]

68. Huxham, C. Theorizing collaboration practice. Public Manag. Rev. 2003, 5, 401-423. [CrossRef]

69. Stringham, E.P. Kaldor-Hicks efficiency and the problem of central planning. Q. J. Austrian Econ. 2001, 4, 41-50.

70. Kim, S.E.; Chai, W.H.; Choi, J.H.; Kim, S.K. A Study of Cooperations among Local Governments. J. Local Gov. Stud. 2009, 21, 97-119.

71. Lim, S.M. Conflict Management and Collaborative Governance in the Intergovernmental Relationship. J. Northeast. Asian Stud. 2006, 11, 101-120. 
72. Nelles, J. Cooperation and Capacity? Exploring the Sources and Limits of City-Region Governance Partnerships. Int. J. Urban Reg. Res. 2013, 37, 1349-1367. [CrossRef]

73. Cho, K.W. Political and Policy Responses to the Sewol Ferry Disaster: Examining Change through Multiple Theory Lenses. Ph.D. Thesis, Florida State University, Tallahassee, FL, USA, 2017, unpublished.

74. Ansell, C.; Gash, A. Collaborative platforms as a governance strategy. J. Public Adm. Res. Theory 2017, 28, 16-32. [CrossRef] 